\title{
Blood Substitutes in Cardiac Surgery
}

\author{
Joyce A. Wahr, $M D$ and Kevin K. Tremper, MD, PhD
}

\begin{abstract}
A safe, inexpensive, noninfectious substitute for red blood cells has long been sought. Despite tremendous advances in blood banking, the logistics of collecting, transporting, and storing human red blood cells continues to create infection and shortage problems. The two basic types of blood substitutes currently under development are hemoglobin based and fluorocarbon based. Although they each transport oxygen differently, the basic advantages and limitations are the same. Blood substitute advantages include the unique capacity for room temperature storage, noninfectivity, adequate supply, and low toxicity. Restrictions include limited dosing in the acute period, limited intravascular half-life and, for the fluorocarbons, a requirement for a high $\mathrm{PaO}_{2}$. In addition, there remain questions about the relationship of nitric oxide metabolism to hypertension in hemoglobin solutions. Early clinical and laboratory trials have shown that both types of solutions are effective oxygen-delivery agents, with acceptable sideeffect profiles. Clinical trials are currently underway to determine the safety and efficacy of these solutions in patients undergoing cardiopulmonary bypass.

Copyright $\odot 1998$ by W. B. Saunders Company.
\end{abstract}

$T$ he War Department (now the Department of Defense) began an earnest search for a blood substitute before World War II. It was recognized that nearly one-third of all battlefield deaths occurred because of hemorrhage alone. The logistics of collecting, storing, transporting, and cross-matching allogeneic blood under battlefield conditions meant that many soldiers died of eminently treatable wounds. The War Department originally sought a hemoglobin solution that could be stored indefinitely at room temperature, preferably in a dessicated form, and be transfused without the need for crossmatching. Nearly 60 years later, blood substitutes appear to be within 2 to 5 years of commercial production. Although the chief reasons for the desirability of these solutions have changed over the years, the most prominent current impetus

From the University of Michigan, Department of Anesthesiology, Ann Arbor, MI.

Address reprint requests to Joyce $A$. Wahr, $M D$, University of Michigan, Department of Anesthesiology, 1500 E Medical Center Dr, Ann Arbor, MI 481090048.

Copyright $\odot 1998$ by W. B. Saunders Company.

1089-2532/98/0204-0003\$08.00/0 for developing these substitutes is the risk of allogeneic transfusion. Although safer than at any time in the past, there are risks inherent to the transfusion of allogeneic blood. ${ }^{1}$

These risks of allogeneic transfusion are primarily immunologic and infectious. ${ }^{2,3}$ Immunologic risks range from hemolytic reaction to incompatible blood (the most common cause of fatality caused by blood transfusion and most often caused by clerical error) ${ }^{3,4}$ to the poorly understood immunomodulation associated with allogeneic blood. ${ }^{5-7}$ Infectious risks include bacterial, rickettsial, and viral vectors, but patients are generally most concerned with the risk of human immunodeficiency virus transmission. The current estimated risks of allogeneic blood transfusion are listed in Table 1.

Awareness of the risks of allogeneic blood transfusion have led to a re-evaluation of blood transfusion practices. The most viable techniques for limiting the use of allogeneic blood are: (1) increased tolerance for anemia, (2) the use of autologous donation, (3) pharmacologic means of decreasing blood loss, and (4) the possible use of blood substitutes. A complete discussion of these four techniques is beyond the scope of this review, but a brief discussion of the limits of anemia is required to understand the potential niche for so-called blood substitutes.

\section{Physiologic Limits of Anemia}

\section{Oxygen Delivery During Anemia}

Several studies suggest that mammals have a large reserve of red blood cells. Normovolemic anemia is well tolerated when there is adequate cardiac reserve to compensate for decreased oxygen-carrying capacity by increased blood flow. Laboratory baboons, dogs, and pigs tolerate acute normovolemic hemodilution to hematocrits as low as $4 \%$ to $7 \%$. The primary compensation involves increased stroke volume down to a hematocrit of approximately $20 \%$ and increased heart rate at lower hematocrits. This compensa- 
Table 1. Estimate of the Current Risk of Blood Transfusion (United States, 1996)

\begin{tabular}{ll}
\hline Minor allergic reactions & $1: 100$ \\
Viral hepatitis & $1: 50,000$ \\
Hemolytic transfusion reaction & $1: 6,000$ \\
Fatal hemolytic reaction & $1: 600,000$ \\
Human immunodeficiency virus infection & $1: 600,000$ \\
Bacterial infection (platelets) & $1: 2,500$ \\
\hline
\end{tabular}

tory increase in cardiac output maintains tissue oxygen delivery despite a decreasing arterial oxygen content. This increased cardiac output, however, increases myocardial oxygen demand at the same time that myocardial oxygen delivery is reduced. In the myocardium, as in the rest of the body, increased oxygen delivery must occur through increased blood flow. In the setting of cardiac surgery, with patients in whom coronary artery flow is already significantly compromised, anemia may result in ischemia. ${ }^{8}$ Defining the limits of anemia in cardiac surgical patients has not been simple.

The majority of studies that attempt to define the limits of anemia in the setting of coronary artery disease $(\mathrm{CAD})$ involve laboratory animals. In a series of canine experiments, Spahn et al showed that: (1) cardiac failure caused by anemia occurs at a higher hematocrit in dogs with coronary stenosis than in dogs without stenosis, (2) the lowest mean hematocrit tolerated without signs of ischemia is $21 \%$ in dogs with stenosis versus $14 \%$ in dogs without; and (3) dogs with multivessel CAD suffer cardiac failure caused by anemia at a higher hematocrit than dogs with single-vessel disease. ${ }^{9-11}$

Studies of the limits of anemia in humans with $\mathrm{CAD}$ are less common. Herregods et $\mathrm{al}^{12}$ performed hemodilution in patients with left main disease and found no signs of ischemia at a hematocrit of $30 \%$. Jalonen et $\mathrm{al}^{13}$ performed hemodilution in 66 patients undergoing coronary artery bypass surgery and found no evidence of ischemia to hematocrits of $28 \%$. At present, there is no evidence that hemodilution to hematocrits less than $28 \%$ is without risk. Nelson et al ${ }^{14}$ presented postoperative data with respect to myocardial ischemia and morbidity in 27 high-risk patients who underwent vascular surgery. The study noted a significant increase in postoperative myocardial ischemia and morbidity (cardiogenic pulmonary edema, myocardial infarction, and cardiac death) when the hemato- crit decreased to $28 \%$ or less. They concluded these data suggest that hematocrits less than $28 \%$ may have a role in postoperative ischemia and cardiac morbidity.

Despite the plethora of evidence that healthy laboratory animals can tolerate hematocrits less than $10 \%$, evidence to date using normothermic human subjects would support maintaining a hematocrit of greater than $28 \%$ in patients with $\mathrm{CAD}$ or providing additional oxygen-carrying capacity above and beyond that of the remaining red cells. It is hoped that the addition of oxygencarrying colloids to provide oxygen delivery reserve during acute normovolemic hemodilution will permit widespread use of this technique during surgery and thereby decrease the use of allogeneic blood transfusions. ${ }^{15,16}$ There are currently two primary types of blood substitutes under development: the hemoglobin-based solutions and the fluorocarbon solutions (Table 2). In truth, neither of these solutions is a blood substitute. Mammalian blood performs a myriad of functions and, as Amberson ${ }^{17}$ wrote in his 1937 review of blood substitutes, blood

$\ldots$ is the most complicated fluid to be found in the
world of living organisms. Compounded of a dozen
essential ingredients sustaining a multiplicity of activi-
ties, the fluid pathway for a variety of chemical and
hormonal integrations of function, the source of food
and oxygen for every tissue, it defies laboratory
synthesis. At the very beginning we must recognize that
there is no complete substitute for blood. ${ }^{17}$

In essence, all the current blood substitutes under development should be defined as oxygencarrying colloids, and because oxygen transport differs among these compounds, a brief review of normal oxygen transport is in order.

\section{Basics of Oxygen Transport}

Oxygenation is adequate when oxygen is being supplied to the tissues at a sufficient rate to maintain aerobic metabolism. Arterial oxygen content is defined as the volume of oxygen (in milliliters) carried in $100 \mathrm{~mL}$ of blood.

$$
\begin{aligned}
\mathrm{CaO}_{2}=\mathrm{Hb} \times 1.37 \times \mathrm{SaO}_{2} & \\
& +0.0034 \times \mathrm{PaO}_{2}
\end{aligned}
$$

in which $\mathrm{CaO}_{2}=$ arterial oxygen content in milliliters per $100 \mathrm{~mL}$ (also called vol \%), $\mathrm{Hb}=$ hemoglobin concentration in grams per deciliter, $1.37=$ the volume of oxygen (in milliliters) 
Table 2. Current Oxygen-Carrying Colloids Under Development

\begin{tabular}{|c|c|c|c|c|}
\hline Product & Manufacturer & Perfluorocarbon & Concentration & Surfactant \\
\hline \multicolumn{5}{|c|}{ Fluorocarbon emulsions } \\
\hline Fluosol DA-20\% & Green Cross Corp, Osaka, Japan & $\begin{array}{l}\text { Perfluorodecaline and } \\
\text { perfluorotriproplyamine }\end{array}$ & $\begin{array}{l}14 \mathrm{~g} / 100 \mathrm{~mL} \\
6 \mathrm{~g} / 100 \mathrm{~mL}\end{array}$ & $\begin{array}{l}\text { Pluronic } \\
\text { F68 }\end{array}$ \\
\hline Oxygent & Alliance Pharm, San Diego, CA & Perfluorooctylbromide & $70 \mathrm{~g} / 100 \mathrm{~mL}$ & Lecithin \\
\hline Oxylluor & Hemagen, St Louis, MO & HM 351 & $80 \mathrm{~g} / 100 \mathrm{~mL}$ & \\
\hline Manufacturer & HB Source & Configuration & Concentration & $\mathrm{P} 5 \mathrm{OmmHg}$ \\
\hline \multicolumn{5}{|c|}{ Stroma-free hemoglobin solutions } \\
\hline Baxter & Human & Cross-linked tetramer & $10 \mathrm{~g} / \mathrm{dL}$ & $32 \mathrm{mmHg}$ \\
\hline Biopure & Bovine & Polymerized & $13 \mathrm{~g} / \mathrm{dL}$ & $34 \mathrm{mmHg}$ \\
\hline Northfield & Human & Polymerized, tetramer-free & $10 \mathrm{~g} / \mathrm{dL}$ & $30 \mathrm{mmHg}$ \\
\hline Somatogen & Recombinant & Genetically fused & $5 \mathrm{~g} / \mathrm{dL}$ & $17.2 \mathrm{mmHg}$ \\
\hline Hemasol & Human & Polymerized & $10 \mathrm{~g} / \mathrm{dL}$ & $32 \mathrm{mmHg}$ \\
\hline Enzol & Bovine & $\begin{array}{l}\text { PEG conjugated non-cross- } \\
\text { linked tetramer }\end{array}$ & $6 \mathrm{~g} / \mathrm{dL}$ & $20 \mathrm{mmHg}$ \\
\hline
\end{tabular}

NOTE. Baxter, Deerfield, IL; Biopure, Boston, MA; Northfield, Evanston, IL; Somatogen, Boulder, CO, Hemasol, Ontario, Canada, Enzol, Piscataway, NJ.

Abbreviations: $\mathrm{Hb}$, hemoglobin; PEG, polyethyleneglycol; P50, the arterial oxygen partial pressure at which $50 \%$ of the hemoglobin is saturated, $50 \%$ is desaturated.

carried by $1 \mathrm{~g}$ of fully saturated hemoglobin, $\mathrm{SaO}_{2}=$ fractional hemoglobin saturation $(\%$ $\mathrm{HbO}_{2}$ /total $\mathrm{Hb}$ ), $0.0034=$ the solubility coefficient of oxygen in plasma (milliliters of oxygen per $100 \mathrm{~mL}$ of plasma per millimeters of mercury), and $\mathrm{PaO}_{2}=$ the arterial oxygen tension in millimeters of mercury.

With a normal $15 \mathrm{~g}$ of hemoglobin and normal arterial $\mathrm{PaO}_{2}$ and $\mathrm{SaO}_{2}$ values of $90 \mathrm{mmHg}$ and $97 \%$, respectively, an arterial oxygen content of $20 \mathrm{vol} \%$ is obtained.

Equation 1 shows that the vast proportion of oxygen is carried by the hemoglobin; relatively little is dissolved in the plasma because of water's low solubility for oxygen. Conversely, once the hemoglobin is fully saturated at $\mathrm{PO}_{2}$ of approximately $90 \mathrm{mmHg}$, as oxygen tension increases, no oxygen is added to the hemoglobin phase while oxygen continues to dissolve in the water phase. If a patient were to breathe hyperbaric oxygen and have a $\mathrm{PaO}_{2}$ of $1,500 \mathrm{mmHg}$, the dissolved oxygen content in the plasma would be approximately $5 \mathrm{vol} \%$, thereby contributing significantly to the oxygen content (Fig 1).

The overall flow rate of oxygen to the tissues is the arterial oxygen content times the cardiac output. At a cardiac output of $5 \mathrm{~L} / \mathrm{min}$, a normal oxygen delivery of $1,000 \mathrm{~mL}$ of oxygen/ min is obtained. A normal cardiac index (cardiac index $=$ cardiac output/body surface area $\left[\mathrm{m}^{2}\right]$ ) is $3 \mathrm{~L} / \mathrm{min} / \mathrm{m}^{2}$ (range, 2.7 to $3.4 \mathrm{~L} / \mathrm{min}$ / $\left.\mathrm{m}^{2}\right)$.

Normal $\mathrm{O}_{2}$ Delivery Index $=20 \mathrm{~mL} / \mathrm{dL}$

$$
\begin{array}{r}
\times 10 \mathrm{dL} / \mathrm{L} \times 3 \mathrm{~L} / \mathrm{min} / \mathrm{m}^{2} \\
=600 \mathrm{~mL} / \mathrm{min} / \mathrm{m}^{2}
\end{array}
$$

The tissues consume an average of $5 \mathrm{~mL}$ of oxygen from every $100 \mathrm{~mL}$ of blood flow, with $75 \%$ of the oxygen remaining in the venous blood. The oxygen consumption of the body can be calculated as follows:

Oxygen consumption index $=\mathrm{VO}_{2}\left(\mathrm{CaO}_{2}-\right.$ $\left.\mathrm{CvO}_{2}\right) \times$ cardiac index.

$$
\begin{aligned}
\mathrm{VO}_{2}= & (20 \mathrm{~mL} / \mathrm{dL}-15 \mathrm{~mL} / \mathrm{dL}) \\
\times 3 \mathrm{~L} / \mathrm{min} / \mathrm{m}^{2} & \times 10 \mathrm{dL} / \mathrm{L} \\
& =150 \mathrm{~mL} / \mathrm{min} / \mathrm{m}^{2}
\end{aligned}
$$

The hemoglobin in blood normally unloads 5 vol \% of oxygen as it passes through the tissues, as shown in Figure 1. The dissolved oxygen in the plasma contributes little under these circumstances, but if the $\mathrm{PO}_{2}$ were increased to 1,500 $\mathrm{mmHg}$, a patient could theoretically survive on the oxygen dissolved in the plasma having a mixed venous hemoglobin saturation of $100 \%$. In this situation, although the plasma only carries a little more than 5 vol $\%$ because it is released to the tissues in a direct proportion to 


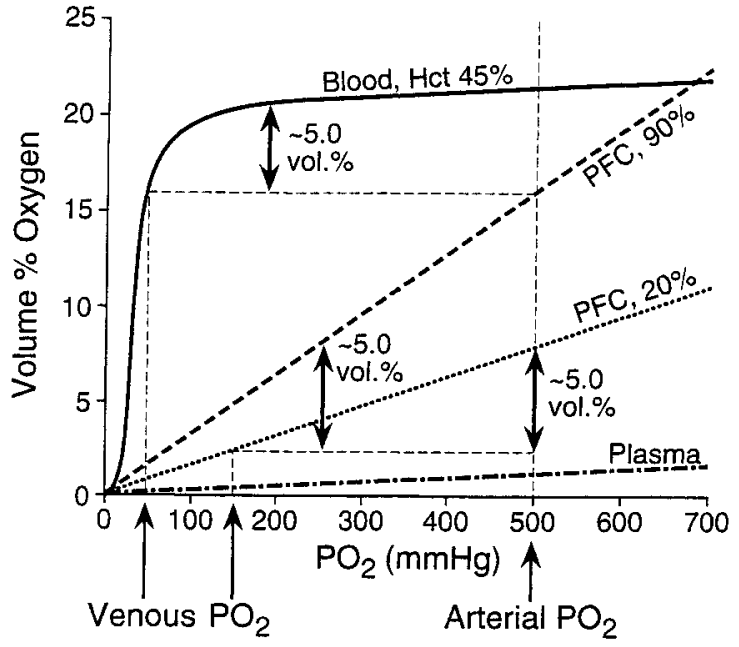

Figure 1. Oxygen content is plotted versus $\mathrm{PO}_{2}$ for blood with hematocrits of $45 \%$ and $12 \%$. At 500 $\mathrm{mmHg}$, blood with hematocrit (HCT) of $45 \%$ has an arterial content of $21 \%$ and a venous content of $16 \%$, but the venous $\mathrm{PO}_{2}$ is in the range of $50 \mathrm{mmHg}$. A $20 \%$ PFC emulsion will have an arterial content of only 7 vol \% but if this same $5 \mathrm{vol} \%$ is extracted, the mixed venous $\mathrm{PO}_{2}$ will be approximately $150 \mathrm{mmHg}$. Content lines drawn for hemoglobin solutions would be similar to blood.

the oxygen tension, nearly all the oxygen is extracted (Fig 1). The understanding of these two methods of oxygen transport (hemoglobin carriage $v$ dissolved carriage) becomes important when the two types of blood substitute are discussed and compared.

\section{Calculation of $\mathrm{O}_{2}$ Content With Oxygen-Carrying Colloids}

Perfluorochemical oxygen content. As shown in Figure 1, perfluorochemicals (PFCs) carry oxygen by direct solubility, as does plasma. The following oxygen content equation has a third term that represents the PFC contribution:

$$
\begin{aligned}
\mathrm{CaO}_{2}= & \mathrm{Hb} \times 1.37 \times \mathrm{SaO}_{2} \\
+0.0034 \times \mathrm{PaO}_{2}+ & 0.057 \\
& \times \frac{\mathrm{Fct}}{100} \times \mathrm{PaO}_{2}
\end{aligned}
$$

in which Fct $=$ fluorocrit, fraction of PFC in blood analogous to hematocrit.
The solubility factor in the third term $(0.057)$ * is nearly 20 times that of the solubility factor for oxygen in plasma $(0.0034) .{ }^{18}$ The PFCs contribution is a direct function of the $\mathrm{PaO}_{2}$ and the volume of PFC present, the fluorocrit, or Fct.

Hemoglobin solutions: oxygen content. If the hemoglobin solution (either stroma free or microencapsulated) has the same P50 as blood (27 $\mathrm{mmHg}$ ), there is no difference in the oxygen content equation. If the P50 of the hemoglobin solution is significantly different from that of blood, the content will vary depending on the concentration of the hemoglobin solution and its saturation. That is, the oxygen tension will be constant and the saturations will vary, as shown:

$$
\begin{aligned}
\mathrm{CaO}_{2}= & \mathrm{FHb} \times 1.37 \times \mathrm{FSaO}_{2}+\mathrm{Hb} \\
& \times 1.37 \times \mathrm{SaO}_{2}+0.0034 \times \mathrm{PaO}_{2}
\end{aligned}
$$

in which $\mathrm{FHb}=$ concentration of hemoglobin solution in blood in grams per deciliter and $\mathrm{FSaO}_{2}=$ saturation of the $\mathrm{FHb}$. The P50s of hemoglobin-based oxygen carriers, as listed in Table 2, are similar to that of normal blood.

\section{Microcirculation and Oxygen-Carrying Colloids}

These oxygen-carrying colloids differ in another way from red cells, and that is in their size range. The hemoglobin solutions range from 68,000 to $500,000 \mathrm{RDA}$ and the fluorochemical emulsion particles are in the range of $0.2 \mu \mathrm{m}$. This size range is within that of many of the plasma proteins. These particles, therefore, can be expected to participate in the extravascular circulation as do plasma proteins. Animal data indicate that these oxygen-carrying colloids leave the intravascular space and rejoin it through the lymphatic circulation (E.E. Jacobs, Jr, personal communication, May 1997). This raises interesting questions about the ability of these colloids to provide oxygen delivery to the extravascular space. In addition, work in microcirculation has shown that capillaries can open and close to red cell flow, but that plasma flow continues even when red cells are not traversing the capillary. Again, because the oxygen-carrying colloids travel

*The factor 0.057 is the solubility of $\mathrm{O}_{2}$ in $P F C$ minus the solubility of $\mathrm{O}_{2}$ in plasma. This is required because as $P F C$ is added to the plasma, there is less plasma available to carry $\mathrm{O}_{2}$. 
in the plasma space, they can provide oxygen delivery to tissues even though red cells are not present in the capillaries. It has been speculated that the oxygen-carrying colloids will provide enhanced tissue oxygen delivery, especially in tissues in which red cell flow is limited.

\section{PFC Emulsions}

In 1965, Clark and Gollan ${ }^{19}$ performed an ingenious experiment that spawned the development of an entirely new concept in oxygen transport. They were experimenting with a new series of compounds known as PFCs because of their unique capacity as chemically inert liquids with extremely high solubilities for gases. These PFCs were composed of 8 to 10 completely fluorinated carbon structures, which made them inert liquids with a density nearly twice that of water. Because their solubility for oxygen was nearly 20 times that of water, these investigators ${ }^{19}$ questioned whether an animal could survive breathing this liquid equilibrated with one atmosphere of oxygen. They submerged a rat in equilibrated liquid for 30 minutes and found the animal suffered no apparent harm. Because these liquids are completely immiscible in water, an intravenous injection is immediately lethal because it would form a liquid embolus.

In 1968 , Gehes et $\mathrm{al}^{20}$ produced a microemulsion (particle size, $0.1 \mu \mathrm{m}$ ) of a PFC in normal saline. They conducted a complete exchange transfusion with a rat that maintained survival breathing $100 \%$ oxygen with a hematocrit of zero. Because of the inertness of these compounds, they are not metabolized but are cleared from the vascular space by the reticuloendothelial (RE) system and ultimately collect in the liver and spleen. The PFC leaves the body slowly, as vapor in the respiratory gas. Because the PFCs transport oxygen by simple solubility, the amount of oxygen carried is directly proportional to the percent of the PFC in the blood stream and the $\mathrm{PaO}_{2}$.

Figure 1 shows the carrying capacity of a theoretical PFC emulsion with a $20 \%$ and a $90 \%$ concentration of PFC. Note that the amount of oxygen carried by a PFC emulsion is substantially less than that of blood with a normal hematocrit. Because the PFC carries oxygen by direct solubility, it also releases it in a direct proportion to the $\mathrm{PO}_{2}$, unlike the cooperative binding effect of hemoglobin. From the preceding description of oxygen transport, the potential contribution of PFCs to oxygen transport may be assessed by looking at mixed venous values of $\mathrm{PO}_{2}$ and the quantity of oxygen consumed by the tissue $\left(\mathrm{CaO}_{2}-\mathrm{CvO}_{2} \approx 5\right.$ vol \%). If a $\mathrm{PvO}_{2}$ of 40 $\mathrm{mmHg}$ and an oxygen extraction of 5 vol \% are assumed, a bloodless animal could survive with fluorocrits of $10 \%, 20 \%$, and $50 \%$ with $\mathrm{PaO}_{2}$ values of 800,650 , and $250 \mathrm{mmHg}$, respectively. From these calculations, it would appear that a patient could survive with a PFC emulsion without red blood cells. Practically, this would be difficult because the emulsion is cleared from the vascular space within 24 hours. Also, because of the long tissue half-time of a PFC in the body (months to years, depending on the PFC compound), it would not be feasible to continuously re-dose the patient.

The primary toxicities of these compounds concern their potential effects on the RE system as they are cleared. No long-term toxicities have been noted, but there are concerns of an RE cell blockade and potential effects on the liver because the $\mathrm{RE}$ system capacity may be overwhelmed when PFCs are cleared from the vascular space.

The primary technical problem in producing a clinically usable product was the development of a stable emulsion that contained sufficient PFC. In the late 1970s, the Green Cross Corporation (Osaka, Japan) developed a product called Fluosol DA-20\%, an emulsion composed of two PFCs (perfluorodecalin and perfluorotripropylamine). ${ }^{18,20}$ The combination of two PFCs was used to take advantage of the emulsion stability of one PFC (perfluorodecalin) and the shorter tissue half-life of the other (perfluorotripropylamine). Even with this mixture, the solution only contained $10 \%$ PFC (Fluosol DA-20\% is $20 \%$ by weight, $10 \%$ by volume). The surfactant used to maintain this emulsion was pluronic F68, an emulsifier that had been used in other medical products. To maintain stability, the product also required freezing until just before use. In the early 1980s, clinical studies were initiated in patients who refused blood transfusions, were actively bleeding, and required surgery. In this unique patient population, $20 \mathrm{~mL} / \mathrm{kg}$ of body weight of emulsion was transfused preoperatively with a maximum of one additional dose postoperatively. ${ }^{21}$ The patients achieved a maximal 
fluorocrit of just less than $3 \%$ with an intravascular half-life of approximately 19 hours. Subsequent studies confirmed the oxygen-carrying contribution of the PFC but could not show a beneficial effect on patient outcome..$^{22}$ Another problem with Fluosol DA-20\% was the appearance of an acute complement-mediated reaction caused by the surfactant, which necessitated pretreatment with corticosteroids for all patients.

Despite these shortcomings, Fluosol DA-20\% is the only oxygen-carrying colloid to gain Food and Drug Administration approval (approved for intracoronary infusion in patients undergoing angioplasty). Fluosol DA-20\% improved myocardial recovery in an isolated neonatal pig heart model. ${ }^{23} \mathrm{~A}$ trial of Fluosol as adjunct reperfusion therapy aimed at preventing reperfusion injury for patients with acute myocardial infarction, however, failed to show any decrease in infarct size or improvement in myocardial function. ${ }^{24}$ The incidence of recurrent ischemia was decreased in patients receiving Fluosol. ${ }^{24}$

Over the past few years, second-generation PFC emulsions have been under development. One of these uses the perfluorocarbon perfluorooctylbromide. ${ }^{25}$ This $\mathrm{PFC}$ is unique in that it has one bromine replacing a fluorine, making it radiopaque. This emulsion, Oxygent (Alliance Pharmaceuticals, San Diego, CA), contains 90\% PFC by weight, or $45 \%$ by volume. It is emulsified with lecithin and is stable at room temperature for more than 6 years. Given the general limitations of PFCs (that they require high inspired oxygen and will have an intravascular half-life of approximately 24 to 36 hours), animal and clinical studies currently underway are investigating this product as an intraoperative oxygen supplement used in conjunction with isovolemic hemodilution. The hopes are this product will supplement oxygen transport intraoperatively, thereby lessening the need for blood transfusions in the postoperative period. The ultimate use of PFC emulsions in the perioperative period has yet to be determined, although one pilot study in surgical patients showed enhanced mixed venous $\mathrm{PO}_{2}$ in patients receiving a perfluorocarbon emulsion. ${ }^{26}$

\section{Hemoglobin Solutions}

As previously noted, numerous difficulties have slowed the development of a hemoglobin-based solution. The first problem is the renal toxicity associated with impurities in the hemoglobin solutions, predominantly from residual red cell membranes (stroma). These problems were first identified by Rabiner et $\mathrm{al}^{27}$ and research since has been directed toward producing a stromafree hemoglobin solution. The second problem is associated with the altered affinity of hemoglobin for oxygen. When hemoglobin is removed from a red blood cell, 2,3-diphosphoglycerate is lost and the normal tetramer dissociates into two $\alpha$ and $\beta$ dimers, changing the oxygen affinity and reducing the $\mathrm{P} 50$ from the normal of 26.7 $\mathrm{mmHg}$ to the range of 12 to $14 \mathrm{mmHg} .{ }^{28}$ The hemoglobin, therefore, picks up oxygen very aggressively but may never release it at the normal oxygen tensions seen in the cardiovascular system. A third problem results from the small size of the hemoglobin dimers. At 32,000 RDA, these dimers are small enough to be diuresed by the kidney. Consequently, when unmodified stroma-free hemoglobin solutions are infused intravascularly, they pick up oxygen and then act as an osmotic diuretic, ultimately reducing the intravascular volume by causing the patient to lose not only hemoglobin, but the oxygen attached to it in the urine. This "red mannitol" effect of the early hemoglobin solutions was resolved by increasing the P50 and increasing the molecular size. Cross-linking the molecule with pyridoxal-5-phosphate or diaspirin compounds has been successful in stabilizing the tetramer and improving the P50 to near the normal range. ${ }^{29}$ The effective size has been further increased by either attaching the hemoglobin molecule to another molecule of larger size or by forming a hemoglobin polymer to increase circulating lifetime. ${ }^{30}$ Again, as with PFCs, the hemoglobin solutions are cleared from the vascular space quickly, in a matter of 24 to 48 hours, depending on the dose.

The hemoglobin used in these solutions comes from a variety of sources. The first is human blood from volunteers, which may face the same limited supply that blood banks now struggle with. Bovine hemoglobin is more readily available, with a supply of nearly 1 million units a day from meat production. Hemoglobin has also been produced using recombinant technology. 30,31

Each of the hemoglobin solutions in clinical trials currently should be considered a different 
drug, each with a unique pharmacokinetic and pharmacodynamic profile. Each of the solutions is derived from a different source, stabilized in a different way (cross-linking $v$ polymerization $v$ genetic mutation), has a different concentration, and should be expected to show a different side-effect profile. To date, there are insufficient data in the literature to assess each of these solutions adequately. Despite their differences, each of the hemoglobin solutions must address the following challenges: limited intravascular half-life, hemodynamic alterations, and interference with clinical laboratory testing.

Like the fluorochemical solutions, the hemoglobin solutions are recognized by the body as an abnormal physiologic event, and the RE system scavenges the particles from the blood stream. The effective life of the hemoglobin solutions is about 24 to 48 hours, depending on the dose. ${ }^{32}$ Therefore, these solutions will, like the PFCs, find their greatest applicability in acute, limited blood-loss situations, perhaps again associated with an autologous hemodilution scheme during surgery. ${ }^{15,16,33}$ Unlike the PFCs, however, hemoglobin solutions may offer a solution to the problem of limited intravascular retention. Animals that are hemodiluted to very low hematocrits and are then transfused with hemoglobin solutions show a dramatic reticulocytosis that exceeds that expected from exogenous erythropoietin. Beagles bled to a hematocrit of $5 \%$ required only two doses of hemoglobin solution over an 8-day period. By day 8 , the average hematocrit had returned to $15 \%$ because of significant red blood cell production (E.E. Jacobs, personal communication, May 1997).

All hemoglobin products also appear to have some hemodynamic effect. As shown in Table 3, all cause some degree of vasoconstriction, especially in the pulmonary vasculature. ${ }^{34.38}$ At first this was believed to be caused by contaminants, but this effect is also seen with genetically derived pure hemoglobin. It has recently been discovered that this vasoconstrictive effect is produced because of hemoglobin's role in nitricoxide equilibrium. ${ }^{3941}$ Nitric oxide is the final common pathway for vasodilatation, once attributed to an unidentified factor called the endothelial cell-derived relaxing factor. Under normal physiologic conditions in which hemoglobin is within the red cell, nitric oxide in the vessel wall is effective in maintaining vasodilatation and is
Table 3. Hemoglobin-Based Oxygen Carriers and Hypertension

\begin{tabular}{lcc}
\hline \multicolumn{1}{c}{ Author } & Solution & $\begin{array}{c}\text { Estimated Change in } \\
\text { Blood Pressure }\end{array}$ \\
\hline Hughes et al $^{32}$ & HBOC-201 & $\begin{array}{c}<5 \text { mm increase in } \\
\text { systolic pressure }\end{array}$ \\
Hess et al $^{34}$ & aa cross-linked & $\begin{array}{c}100 \% \text { increase in pul- } \\
\text { monary pressure }\end{array}$ \\
Ulatowski et al ${ }^{35}$ & HBOC-201 & $40 \%$ increase in sys- \\
& temic pressure \\
Hughes et al ${ }^{36}$ & HBOC-201 & $25 \%$ increase in sys- \\
& & temic pressure \\
& & $25 \%$ increase in sys- \\
& & temic vascular resis- \\
& & tance \\
\hline
\end{tabular}

removed as it dissolves into the plasma and ultimately attaches to the hemoglobin. When hemoglobin is free in solution, it appears to scavenge nitric oxide to a greater extent, thereby causing vasoconstriction. Because of the limited clinical experience with these solutions to date, it is not clear what the magnitude or clinical significance of the hemodynamic effect will be. This appears to be a basic characteristic of the hemoglobin molecule and is one of its physiologic functions. No method has been postulated to modify the stroma-free hemoglobin solutions to reduce its effect on nitric oxide and the resulting vasoconstriction. Encapsulation of the hemoglobin into liposomes may resolve this issue.

Finally, all hemoglobin solutions interfere with spectrophotographic laboratory determinations of the concentrations of certain plasma constituents (D. Giacherio, personal communication, February 1996). Because of its lightabsorbing quality, plasma hemoglobin, in concentrations of approximately $2 \mathrm{~g} / \mathrm{dL}$, interferes significantly with a wide variety of serum chemistry determinations. Although other means of determining these lab values are available, spectrophotometric methods are so ubiquitous that widespread use of the hemoglobin solutions will require some adaptation.

Despite these limitations, clinical studies are currently underway to investigate the safety and efficacy of a variety of hemoglobin solutions. The advantages and limitations of the oxygen-carrying colloids are listed in Table 4.

In an attempt to address some of the issues associated with the stroma-free hemoglobin solutions, efforts have been directed to microencap- 
Table 4. Advantages and Limitations of the Oxygen-Carrying Colloids

\begin{tabular}{|c|c|c|}
\hline & $\begin{array}{l}\text { Fluorocarbon } \\
\text { Solutions }\end{array}$ & $\begin{array}{l}\text { Hemoglobin } \\
\text { Solutions }\end{array}$ \\
\hline \multirow[t]{5}{*}{ Advantages } & $\begin{array}{l}\text { Linear delivery of } \\
\mathrm{O}_{2}\end{array}$ & $\begin{array}{l}\text { Oxygen dissocia- } \\
\text { tion similar to } \\
\text { red blood cell }\end{array}$ \\
\hline & $\begin{array}{l}\text { Room temperature } \\
\text { storage }\end{array}$ & $\begin{array}{l}\text { Room temperature } \\
\text { storage }\end{array}$ \\
\hline & $\begin{array}{l}\text { Extravascular } \\
\text { circulation }\end{array}$ & $\begin{array}{l}\text { Extravascular circu- } \\
\text { lation }\end{array}$ \\
\hline & Inert & Normal $\mathrm{PaO}_{2}$ \\
\hline & Ample supply & \\
\hline \multirow[t]{3}{*}{ Limitations } & $\begin{array}{l}\text { Limited intravas- } \\
\text { cular life }\end{array}$ & $\begin{array}{l}\text { Limited intravas- } \\
\text { cular life }\end{array}$ \\
\hline & $\begin{array}{l}\text { Requires high pres- } \\
\text { sure of partial } \mathrm{O}_{2}\end{array}$ & $\begin{array}{l}\text { Adverse hemody- } \\
\text { namic affect }\end{array}$ \\
\hline & $\begin{array}{l}\text { Platelet count } \\
\text { decrease }\end{array}$ & $\begin{array}{l}\text { Interference with } \\
\text { lab testing }\end{array}$ \\
\hline
\end{tabular}

sulate hemoglobin. Encapsulation may offer the following advantages: (1) decrease in the magnitude of chemical modification to preserve hemoglobin function; (2) increase in oxygen-transport capacity by including an allosteric effector; (3) provide the opportunity to include other enzymes, such as methemoglobin reductase, thereby preserving more of hemoglobin's natural functions; (4) permit a longer intravascular half-life through manipulation of capsule composition and size; and (5) prevent direct contact of the hemoglobin with blood. ${ }^{39}$ Gelatin and polyamide were initially attempted as encapsulating proteins, with little success. More recently, liposomes, bimolecular lipid membranes, have been used..$^{39,4245}$ Hemoglobin liposomes, variously called hemosomes, liposome-encapsulated hemoglobin, and neo red cells, are able to carry as much oxygen as an equal amount of blood, and have a P50 of approximately 40 $\mathrm{mmHg}$ at $37^{\circ} \mathrm{C}, 45$ although maintaining a lower viscosity. ${ }^{39}$ Like the stroma-free hemoglobin solutions, liposome-encapsulated heme can be stored in a frozen or desiccated state, offering good storage capability. Like the stroma-free hemoglobin solutions, formation of methemoglobinemia remains an issue, but this may be resolved by the addition of methemoglobin reductase to the heme liposome. From the few laboratory studies performed to date, it appears that the circulation half-life is similar to that of stroma-free hemoglobin and fluorocarbons, and that removal is primarily through the $R E$ system.
It is uncertain whether further developments in liposome technology will be able to resolve the chief problem with the proposed blood substitutes, namely that of a short circulation half-life.

\section{Oxygen-Carrying Colloids in Cardiopulmonary Bypass}

The technique of cardiopulmonary bypass resulted in the development of a wide variety of life-saving cardiac surgeries. It has altered the expected outcome of nearly every cardiac disease and dramatically changed the mortality associated with these disorders. Nonetheless, it is an assault to the normal homeostasis system. The exposure of the blood elements to artificial surfaces, the wide fluctuations in body temperature, and the addition of large doses of heparin and protamine all incite an inflammatory response that can result in widespread coagulation abnormalities and reperfusion injury. ${ }^{46-48}$ Additional injury may occur as the myocardium is rendered ischemic for a variable length of time. During this ischemia, the myocardium is protected by reducing oxygen requirements. Paralysis of the muscle and extreme cooling are the mainstays of myocardial protection, but at $9^{\circ} \mathrm{C}$, hemoglobin releases little oxygen to the tissues. The linear relationship between $\mathrm{PaO}_{2}$ and PFC oxygen content offers a potential advantage during CPB. Because this relationship is not affected by decreasing temperature, cardioplegic solutions that contain PFC could theoretically provide oxygen delivery during the period of aortic cross-clamp. Because the $\mathrm{P} 50$ of the hemoglobin solutions is temperature dependent, they would not be expected to be useful in this setting. Although there is some laboratory evidence that both the hemoglobin and fluorocarbon solutions can ameliorate myocardial or cerebral ischemic injury, ${ }^{23,49-53}$ whether these same results can be replicated in human patients remains to be seen.

The blood substitutes may also offer advantages in terms of diminution of the inflammatory response during the period of cardiopulmonary bypass. If oxygen delivery during bypass could be provided with one of the blood substitutes, theoretically, a significant proportion of the patient's blood could be removed and stored to be transfused at the end of CPB. ${ }^{54}$ Whether this 
would reduce the inflammatory response to $\mathrm{CPB}$ is also unknown at this time.

\section{Other Blood Substitutes}

As alluded to previously, no blood substitute currently under development does more than replace the oxygen-carrying function of blood. Another key function of blood is hemostasis, and transfusion of plasma and platelets carries the same infectious and immunomodulatory consequences as do red cell transfusions. The decimation of the factor-deficient population by the human immunodeficiency virus spurred development of recombinant-derived factor VIII and IX, and the same technology will probably be applied to all the coagulation factors in the future. Platelets, with their key role in maintaining hemostasis, are to date available only as allogeneic transfusions, but development of platelet substitutes has begun. Rybak and Renzulli ${ }^{5 \tilde{5}}$ reported on the hemostatic efficacy of a liposomebased plateletsome. These researchers incorporated a deoxycholate extract of a platelet membrane fraction (15 proteins, including GPIb, GPIIIb-IIIa, and GPIV/III) into lipid-based microvesicles. These plateletsomes decreased rat-tail bleeding time in thrombocytopenic animals by $67 \%$. Despite the challenges that must be met before any such platelet substitute is commercially available, these results are promising.

\section{Conclusion}

In conclusion, both PFCs and hemoglobin solutions may find useful niches in a variety of clinical settings in which an oxygen-carrying drug may benefit a specific organ or clinical situation. The hemoglobin solutions may be more useful as field resuscitation fluids before hospital admission, whereas PFCs may be useful in an intraoperative setting. Neither of the oxygen-carrying solutions as currently designed will provide prolonged benefit and may only be useful to reduce the amount of allogeneic blood required, not totally replace it. Of course, neither of these products will benefit or supplement the coagulation cascade and may actually have a detrimental effect, at least by dilution. Ultimately, a combination of allogeneic and autologous blood products, intraoperative and postoperative blood salvage techniques, and these oxygen-carrying solutions may provide an overall system for reducing mortality, morbidity, and costs associated with blood transfusions.

\section{References}

1. Newman R, Podolsky D: Bad blood. U S News World Rep (June 27):68-78, 1994

2. Nicholls MD: Transfusion: Morbidity and mortality. Anaesth Intensive Care 21:15-19, 1993

3. Sazama K: Report of 355 transfusion-associated deaths: 1976-1985. Transfusion 30:583-590, 1990

4. Myhre BA: Fatalities from blood transfusion. JAMA 244:1333-1335, 1980

5. Blumberg N, Triulzi DJ, Heal JM: Transfusion-induced immunomodulation and its clinical consequences. Transfus Med Rev 4:24-35, 1990

6. Bordin JO, Blajchman MA: Immunosuppressive effects of allogeneic blood transfusions: Implications for the patient with a malignancy. Hematol Oncol Clin North Am 9:205-218, 1995

7. Landers DF, Hill GE, Wong KC, Fox IJ: Blood transfusioninduced immunomodulation. Anesth Analg 82:187-204, 1996

8. Crystal GJ: Myocardial oxygen supply-demand relations during isovolemic hemodilution. Adv Pharmacol 31:285312, 1994

9. Spahn DR, Smith LR, Veronee CD, et al: Acute isovolemic hemodilution and blood transfusion. Effects on regional function and metabolism in myocardium with compromised coronary blood flow. J Thorac Cardiovasc Surg 105:694704, 1993

10. Spahn DR, Smith LR, McRae RL, Leone BJ: Effects of acute isovolemic hemodilution and anesthesia on regional function in left ventricular myocardium with compromised coronary blood flow. Acta Anaesthesiol Scand 36:628-636, 1992

11. Spahn DR, Smith LR, Schell RM, et al: Importance of severity of coronary artery disease for the tolerance to normovolemic hemodilution. Comparison of singlevessel versus multivessel stenoses in a canine model. J Thorac Cardiovasc Surg 108:231-239, 1994

12. Herregods L, Foubert L, Moerman A, et al: Comparative study of limited intentional normovolaemic haemodilution in patients with left main coronary artery stenosis. Anaesthesia 50:950-953, 1995

13. Jalonen J, Meretoja O, Laaksonen V, et al: Myocardial oxygen balance during hemodilution in patients undergoing coronary artery bypass grafting. Eur Surg Res $16: 141-147,1984$

14. Nelson AH, Fleisher LA, Rosenbaum SH: Relationship between postoperative anemia and cardiac morbidity in high-risk vascular patients in the intensive care unit. Crit Care Med 21:860-866, 1993

15. Klein HG: Oxygen carriers and transfusion medicine. Artif Cells Blood Substit Immobil Biotechnol 22:123-135, 1994

16. Slanetz PJ, Lee R, Page R, et al: Hemoglobin blood substitutes in extended preoperative autologous blood donation: An experimental study. Surgery 115:246-254, 1994 
17. Amberson WR: Blood Substitutes. Biol Rev 12:48-86, 1937

18. Tremper KK, Levine EM, Waxman K: Clinical experience with Fluosol DA (20\%) in the United States, in Tremper KK (ed): International Anesthesiology Clinics: Perfluorochemical Oxygen Transport 23:185-198, 1985

19. Clark LC, Gollan F: Survival of mammals breathing organic liquids equilibrated with oxygen at atmospheric pressure. Science 152:155-156, 1966

20. Geyer RP, Monroe RG, Taylor K: Survival of rats having red cells totally replaced with emulsified fluorocarbon. Fed Proc 27:384, 1968

21. Tremper KK, Friedman AE, Levine EM: The preoperative treatment of severely anemic patients with perfluorochemical emulsion oxygen transporting fluid, FluosolDA. N Eng J Med 307:277-283, 1982

22. Gould SA, Rosen AL, Sehgal LR, et al: Fluosol-DA as a red-cell substitute in acute anemia. N Engl J Med 314:1653-1656, 1986

23. Martin SM, Laks H, Drinkwater DC, et al: Perfluorochemical reperfusion yields improved myocardial recovery after global ischemia. Ann Thorac Surg 55:954-960, 1993

24. Wall TC, Califf RM, Blankenship J, et al: Intravenous Fluosol in the treatment of acute myocardial infarction. Results of the Thrombolysis and Angioplasty in Myocardial Infarction 9 Trial. TAMI 9 Research Group. Circulation 90:114120, 1994

25. Keipert PE, Faithfull NS, Bradley JD, et al: Enhanced oxygen delivery by perflubron emulsion during acute hemodilution. Artif Cells Blood Substit Immobil Biotechnol 22:1161-1167, 1994

26. Wahr JA, Trouwborst A, Spence RK, et al: A pilot study of the effects of a perflubron emulsion, AF 0104, on mixed venous oxygen tension in anesthetized surgical patients. Anesth Analg 82:103-107, 1996

27. Rabiner SF, O'Brien K, Peskin GW, Friedman LH: Further studies with stroma-free hemoglobin solution. Ann Surg 171:615-622, 1970

28. Klocke R: Effect of alterations in oxygen binding to hemoglobin on oxygen delivery. Pulm Critical Care Update $6: 1-7,1990$

29. Bunn HF: The use of hemoglobin as a blood substitute. Am J Hematol 42:112-117, 1993

30. Bunn HF: The role of hemoglobin-based blood substitutes in transfusion medicine. Transfus Clin Biol 2:433439,1995

31. Leone B: Potential clinical applications of recombinant human haemoglobin in blood conservation. Biodrug 1997 (in press)

32. Hughes G Jr, Francome SF, Antal EJ, et al: Hematologic effects of a novel hemoglobin-based oxygen carrier in normal male and female subjects. J Lab Clin Med 126:444-451, 1995

33. Lee R, Neya K, Svizzero TA, Vlahakes GJ: Limitations of the efficacy of hemoglobin-based oxygen-carrying solutions. J Appl Physiol 79:236-242, 1995

34. Hess JR, MacDonald VW, Brinkley WW: Systemic and pulmonary hypertension after resuscitation with cell-free hemoglobin. J Appl Physiol 74:1769-1778, 1993

35. Ulatowski JA, Koehler RC, Nishikawa T, et al: Role of nitric oxide scavenging in peripheral vasoconstrictor response to beta cross-linked hemoglobin. Artif Cells Blood Substit Immobil Biotechnol 23:263-269, 1995

36. Hughes G Jr, Antal EJ, Locker PK, et al: Physiology and pharmacokinetics of a novel hemoglobin-based oxygen carrier in humans. Crit Care Med 24:756-764, 1996

37. Gulati A, Sharma AC, Burhop KE: Effect of stroma-free hemoglobin and diaspirin cross-linked hemoglobin on the regional circulation and systemic hemodynamics. Life Sci 55:827-837, 1994

38. Winslow RM: Vasoconstriction and the efficacy of hemoglobin-based blood substitutes. Transfus Clin Biol 1:9-14, 1994

39. Usuba A, Miyazawa M, Motoki R, et al: Oxygen transport capacity and hemodynamic effect of newly developed artificial blood "Neo Red Cells (NRC)." Int J Artif Organs 16:551-556, 1993

40. Thompson A, McGarry AE, Valeri CR, Lieberthal W: Stroma-free hemoglobin increases blood pressure and GFR in the hypotensive rat: Role of nitric oxide. J Appl Physiol 77:2348-2354, 1994

41. Sherman IA, Dlugosz JA, Perelman V, et al: Systemic hemodynamic and hepatic microvascular responses to a $33 \%$ blood volume exchange with whole blood, stromafree hemoglobin, and oxypolyhemoglobin solutions. Biomater Artif Cells Immobilization Biotechnol 21:537-551, 1993

42. Tsuchida E, Komatsu T: Synthetic hemes. Methods Enzymol 231:167-193, 685-687, 1994

43. Rudolph AS, Cliff RO, Klipper R, et al: Circulation persistence and biodistribution of lyophilized liposomeencapsulated hemoglobin: An oxygen-carrying resuscitative fluid. Crit Care Med 22:142-150, 1994

44. Rudolph AS: Biomaterial biotechnology using selfassembled lipid microstructures. J Cell Biochem 56:183187,1994

45. Deshpande SV, Beissinger RL: Liposome-encapsulated hemoglobin using film hydration processing to form artificial red blood cells. Biomater Artif Cells Immobil Biotechnol 21:135-145, 1993

46. Elgebaly SA, Houser SL, el Kerm AF, et al: Evidence of cardiac inflammation after open-heart operations. Ann Thorac Surg 57:391-396, 1994

47. Engelman RM, Rousou JA, Flack J, et al: Influence of steroids on complement and cytokine generation after cardiopulmonary bypass. Ann Thorac Surg 60:801-804, 1995

48. Kawahito K, Kawakami M, Fujiwara T, et al: Proinflammatory cytokine levels in patients undergoing cardiopulmonary bypass. Does lung reperfusion influence the release of cytokines? ASAIO J 41:M775-M778, 1995

49. Zhao L, Smith JR, Eyer CL: Effects of a $100 \%$ perfluorooctylbromide emulsion on ischemia/reperfusion injury following cardioplegia. Artif Cells Blood Substit Immobil Biotechnol 23:513-531, 1995

50. Premaratne S, Harada RN, Chun P, et al: Effects of perfluorocarbon exchange transfusion on reducing myocardial infarct size in a primate model of ischemiareperfusion injury: A prospective, randomized study. Surgery 117:670-676, 1995

51. Kloner RA, Hale S: Cardiovascular applications of fluoro- 
carbons in regional ischemia/reperfusion. Artif Cells Blood Substit Immobil Biotechnol 22:1069-1081, 1994

52. Cole DJ, Schell RM, Drummond JC, Reynolds L: Focal cerebral ischemia in rats. Effect of hypervolemic hemodilution with diaspirin cross-linked hemoglobin versus albumin on brain injury and edema. Anesthesiology 78:335-342, 1993

53. Cole DJ, Schell RM, Drummond JC: Diaspirin cross- linked hemoglobin (DCLHb): Effect of hemodilution during focal cerebral ischemia in rats. Artif Cells Blood Substit Immobil Biotechnol 22:813-818, 1994

54. Spiess BD, Cochran RP: Perfluorocarbon emulsions and cardiopulmonary bypass: A technique for the future. J Cardiothorac Vasc Anesth 10:83-90, 1996

55. Rybak ME, Renzulli LA: A liposome-based piatelet substitute, the plateletsome, with hemostatic efficacy. Biomater Artif Cells Immobil Biotechnol 21:101-118, 1993 